\title{
Stolen Trophies: Hunting in Africa Perpetuates Neo-Colonial Attitudes and is an Ineffective Conservation Tool
}

\author{
Meghan Bird
}

Trophy hunting is the sport of tracking and killing a wild animal with desirable traits, such as large antlers on deer, to mount the remains as a symbol of the hunt's success (Sexton). In America, approximately eleven percent of men and one percent of women partake in some form of hunting (Simon 19); this totals nearly 39 million individuals. Of those hunters, 18,500 hunt in Africa each year (Lindsey et al. 881). Enticing these hunters are the claims of trophy hunting organizations, such as Safari Club International and Sportsmen for Fish and Wildlife, who "promote and defend... the role that hunters and hunting organizations have played in protecting wilderness and wildlife" (Simon 17). Considering the massive industry that trophy hunting has become in recent decades (Simon 19), an important question to ask is; does trophy hunting actually have a positive effect on wildlife conservation in Africa? This paper argues that trophy hunting in Africa is not an effective tool for conservation. In fact, the trophy hunting industry is rife with mismanagement and corruption, harmful to animal populations, and grounded in colonial systems that have marginalized, and continue to marginalize local African populations. This argument is integrative as it combines the knowledge of numerous disciplines: the fields of 
anthropology, ecology, economics, ethology, history, indigenous studies, literature studies, and political science are all addressed, among others. A variety of ways of knowing are also incorporated into this argument, including traditional indigenous and analytical ways of knowing. Inquiry and discussion-based study was also employed during argument construction. This argument is established in four major steps. First, the foundations of the trophy hunting industry are analyzed, with references to early indigenous ways of knowing, colonial literature, and neocolonial theory. Second, knowledge of animal behaviour, as well as data regarding quotas and mismanaged funds is presented in an effort to deconstruct misconceptions surrounding trophy hunting as a tool for generating revenue. Subsequently, the establishment of game reserves, the poaching industry, and modern social movements in North America are discussed to illustrate further nuances surrounding the trophy hunting industry. Lastly, propositions for future improvements to the industry are made, by pointing to the case of Namibia, where trophy hunting has benefited locals, animal populations, and the Namibian economy.

\section{Foundations of African Trophy Hunting}

The history of trophy hunting in Africa does not begin with American hunters, but with the colonization of African nations. African people have had a harmonious relationship with nature for centuries; many native African communities have "a complex, symbolic world developed around hunting and its products" (Beinhart et al. 62). Singers would praise the powers of wild animals, on which they relied for survival (62). The San people of South Africa are just one example of many; they "depended on hunting, gathering plants, and foraging... [and] ate fifty-five different animal species" (Beinhart et al. 59). This balanced relationship that many African people had with their environment is very different from the relationship that European colonists had with nature when they settled the coast of Africa in the nineteenth cen- tury (59). Colonists exploited the riches of nature at astounding rates, largely through the exportation of one 'natural resource': ivory (58). Through the exportation of ivory, colonists benefited economically, which encouraged further penetration of the African continent (58, 59). Ivory was also a symbol of wealth in many Victorian-era English homes, and was used to make piano keys, billiard balls, and "carved ornaments" (67). There was such a demand for ivory products, and the symbolic value associated with their possession, that one African port alone demanded "the slaughter of 25,000 [elephants]" (67) to meet the desire for ivory products in the nineteenth century. This colonial narrative illustrates how the tradition of non-indigenous peoples hunting in Africa was founded on exploitation and conquest. Unfortunately, this narrative has changed little since colonial times.

As can be seen from Africa's colonial history, trophy hunting is, in its nature, about power. For centuries it was marketed as "an armed confrontation between the human world and the untamed wilderness" (Whittle 197). Famous novelist and hunter Ernest Hemingway highlights this imperialist mentality in his novel, The Green Hills of Africa:

. . never fire a shot unless I saw a better head than this one in back,

And instead of trailing that sable bull, gut-shot to hell, all day,

I'd lie behind a rock and watch them on the hill side and

See them long enough so they belonged to me forever (Hemingway $62)$.

This literary reference illustrates how hunting mentalities permeated throughout, and were largely accepted in various aspects of Western society in the early 20th century when this Hemingway classic was first published. Unfortunately, this perception of trophy hunting led to 
hunters viewing their environment as a playground, with "indigenous populations only as guides... and the fauna as trophies to be won and displayed as symbols of hunting prowess" (Whittle 196). Even as early as the fifteenth century, Englishmen recognized that usurping power was an aspect of hunting. This can be seen from the noblemen who would ride through the countryside on horseback, passing peasants who were banned from hunting due to their lower social status (Cartmill 773). Today's hunters who travel to Africa continue to express this symbolic lust for power, manifested in neo-colonial actions. The word neo-colonialism was coined by Ghana's first president and anti-colonialist, Nkrumah: "The essence of neocolonialism is that the state which is subject to it is, in theory, independent and has all the outward trappings of international sovereignty. In reality its economic system and thus its political policy is directed from outside" (Antwi-Boateng 177). The way in which trophy hunting usurps power from nature began to be noticed by the public in recent decades, leading to an increased opposition to hunting among Europeans and North Americans (MacDonald et al. 266). In response to this opposition, hunting organizations, such as the Safari Club International, attempted to shift the dialogue surrounding trophy hunting. This has resulted in an increased focus on conservation and responsibility for the environment (Simon 17). Nonetheless, the power narrative remains in the hunting industry, with colonial traditions serving as a backbone for its endeavours. Kenneth MacDonald, from the University of Toronto, discusses this phenomenon at length: "This contemporary reworking of a colonialist ethic of conservation relies rhetorically on a discourse of global ecology, and on ideological representations of a resident population as incapable environmental managers, to assert and implement an allegedly scientifically and ethically superior force better able to respond to assumed degradation" (MacDonald 259). MacDonald explains that the trophy hunters who travel to Africa subscribe to the patronizing be- lief that the fees they pay to hunt are helping African locals take care of the wildlife they cannot take care of themselves. However, one could argue that had it not been for the exploitation of African wildlife since the colonization of African nations, there would not be a need for conservation in Africa in the first place.

\section{African Trophy Hunting and Conservation}

In 2014, the Dallas Safari Club, a Texasbased hunting outfitter, held a fundraiser for conservation efforts in Namibia. One of the ways in which the outfitter accumulated funds was through the auctioning of a permit to shoot a critically endangered African black rhinoceros (Pearce 4). At the time, less than 4000 African black rhinoceroses existed in the world (Christ). The purchaser of the permit, an American father of two daughters, named Corey Knowlton, paid nearly $\$ 450,000$ for the permit (Pearce 4 ). Since Knowlton was only allowed to kill an elderly male rhinoceros, well past reproductive age (Christ), in the eyes of many, this fundraiser was a perfect example of utilizing the hunting industry as a tool for conservation. Unfortunately, this example is a testament to the complete ineffectiveness of trophy hunting as a means for conservation.

In the trophy hunting industry, shooting a young, female, or reproductively viable animal is often illegal (Lindsey et al. 882). Hunters are typically only allowed to kill senior males. However, few hunters understand the complex behaviours and social structures of species that make the deaths of older males devastating to entire populations. In elephants, for example, the eldest males in a population often acts as role models to younger individuals. They carry information about migration patterns and family history that is vital to the survival of the community (Chancellor). A study recently completed by biologist, Victor Muposhi and colleagues analyzed changes in animal behaviour due to the presence of hunters. The results showed that wildlife species develop mechanisms to evade trophy hunting disturbances, such as reducing reproduction, suppressing immunity, and decreas- 
ing population growth (Muposhi 6). Trophy hunting may also induce nutritional stress and reduce animal resilience to parasitic infections and disease (6). This study, as well as the other examples provided, shows that North American trophy hunters are clearly not aware of, or choose to ignore the negative impacts they are having on wildlife in Africa. This can be seen even more clearly when one considers the customs of trophy hunters to hunt animals with 'desirable traits', such as long tusks and thick manes. Evolutionary biologists are aware of the dangerous practice of 'selectively harvesting' certain characteristics, as it has led to a decline in phenotypic traits in animal populations (Muposhi 7). A decrease in these traits can negatively impact populations, since many of the characteristics most desired by hunters are necessary for animal mating practices, self-defence, and survival (Nelson 65).

Regulations regarding the age and gender of a hunter's kill are just one example of ineffective regulations in the trophy hunting industry. Quotas, which are put in place to prevent overhunting, are another equally ineffective example. Though seemingly well-intended, quotas are often based on unreliable population estimates (Baker 313). Such was the case in Tanzania. In 1995 a newspaper reported that the large cat quota of 124 animals, given to the Tanzania Game Tracker Safaris, regarded "areas which do not have [cats] in the first place" (Baker 314). Failure to provide accurate hunting quotas is often caused by a lack of resources, which is a common problem among African wildlife departments (Lindsey et al. 880). As well, the high influx of North American hunters travelling to Africa has created "pressure for increased quotas and smaller hunting areas" (881). According to an article published in the Journal of Sustainable Tourism in 2010, the past several years have seen "a proliferation of hunting companies all vying for blocks in which to satiate their clients' appetite for hunting" (Baker 315). Consequently, numerous hunting parties are active in the same area, leading to an exponential increase in the number of animals killed for trophies (316-17).
When it comes to trophy hunting and conservation, the so-called 'elephant in the room' is the question of generated revenue; how much income is accumulated from the trophy hunting industry, and where does it go? The average trophy hunt costs an American client between $\$ 12,500$ for a water buffalo to $\$ 125,000$ for an endangered white rhinoceros (Azzentine). The majority of clients who can afford to pay these fees are disproportionately white, middle-aged, conservative, higher-income clients (Simon 22), and they are often shrouded in the belief that their money is not only funding their own adventure, but also furthering conservation efforts (Cartmill 784). Unfortunately, this belief is mere myth, which can be seen by the fact that trophy hunting revenue rarely goes solely towards conservation efforts (Baker 311). According to statistics published in the Journal of Sustainable Tourism in 2010, $40 \%$ of the money accumulated from initial fees paid by American hunters goes towards African governments (311), and this is a more liberal estimate. Of that $40 \%$, a possible $10 \%$ goes towards so-called 'conservation efforts' (311). This small sum of money is rarely adequate, as the 12,000 square miles of hunting area in Tanzania alone require 600 million dollars of investment each year (312). And according to American lion biologist, Craig Packer, "You're not going to get that [much money] shooting lions" (Chancellor). Peter Lindsey and colleagues from Cape Town, South Africa agree: "... Trophy hunting frequently fails to generate enough income to manage wildlife land effectively, typically generating only $\$ 138-1,091 / \mathrm{km} 2$ in gross income" each year (Lindsey et al. 297). The chances of this income actually serving conservation efforts are further lessened, as the industry is undermined by corruption in a vast majority of African countries (298). This allows for "unscrupulous operators to continue accessing and depleting hunting areas at the expense of more conservation-minded industry players" (297).

As mentioned earlier, the trophy hunting industry is attempting to change the way the 
public views hunting for sport. Jon Wemple, president of the Western Montana branch of Safari Club International, clearly subscribes to the narrative of hunting as a means of conservation: "I am reminded of the importance of preserving our hunting heritage. [When] species [are] nearly lost... the true conservationists (hunters) step up to the plate" (Simon 17). If trophy hunters claim they are capable of 'stepping up to the plate' then they must, and soon. Trophy hunting outfitters, clubs, African governments, and American clients must take concrete steps to improve the sustainability and transparency of the hunting industry. Otherwise, the treasured lions, rhinoceroses, gazelles, and elephants of the African savannah will remain only on the walls of trophy hunters' living rooms.

\section{African Trophy Hunting's Impact on Ru- ral African Communities}

Many conservation efforts have the contorted view that Africa must be preserved as a pure, unadulterated "state of Eden" (Hubschle 431). However, trying to preserve ecosystems in a pristine state to save wildlife is impractical when local African communities are living in poverty (Baker 307). In the history of dramatic conflicts between white men and nature in Africa, it can be argued that the groups of individuals who have suffered the most are not endangered animal species, but human native populations. According to Annette Hubschle, in the nineteenth century, game reserves were designed to provide "free from all human interference, a sanctuary in which certain species of wildlife could prosper" (431). This meant that indigenous property, hunting rights, and ancestral burial grounds were not considered when protected areas were declared (431). In the twenty-first century, with the spread of the 'trophy hunters as environmentalists' mentality, native populations continue to be oppressed in the name of conservation. In Mozambique in 2001, for example, a new conservation area was declared; however, the land allocated for wildlife protection was home to 27,000 people and their cattle (431). Ultimately, "in- ternational experts recommended that the new conservation area would be more attractive to tourist operators if the villages were resettled" (432). This meant that thousands of people were forced to find new homes, to make "space for wild animals" that did not yet live there but were to be reintroduced into the area (433). In many cases, trophy hunters encourage indigenous displacements, such as this instance in Mozambique. Hunters who are involved in conservation in Africa want their money to go towards creating new protected lands, as they believe this will ensure the existence of hunting ranges and animal specimens in the future (Macdonald 283). However, these efforts are neo-colonial in naturewhen arranged from abroad without considering the livelihoods of locals. These situations worsen further when the leaders in conservation projects subscribe to the notion that the local populations are 'primitive' and unable to care for the wildlife on their own land without the money and assistance of foreigners (MacDonald 267). These neo-colonial conservation practices are incredibly significant yet become even more consequential when one considers that they may be perpetuating the infamous poaching industry.

It is a well-known fact that trophy hunters are opposed to poaching, which is the illegal hunting of wild animals, commonly to sell animal products, such as rhinoceros' horns abroad (Lindsey et al. 297). The vast majority of the North American public is opposed to poaching. The deaths of giraffes, lions, and elephants are often advertised as global catastrophes, despite the fact that most Americans have little understanding of these animals beyond the pages of children's books or the metal bars of a zoo exhibit. Poaching is one of the leading causes of animal endangerment worldwide (Beinhart et al. $62)$, yet the practice is widely misunderstood. Few trophy hunters recognize the deeply entrenched connection between hunting and poaching. A Mozambican local described this relationship in regards to rhinoceros poaching; "This [rhinoceros poaching problem] is because of con- 
servation. They say that we need those things [rhinoceroses]. They are nice. Some of the white people here treat them like their friends. They value the rhino more than black human beings" (Hubschle 440). The current system of conservation in Africa involves the creation of new conservation regions at the expense of local populations, as could be seen in Mozambique in 2001. This system fosters a poaching industry; rural Africans, who have been relocated to living on the fringes of conservation areas, are enticed to illegally hunt and sell animals, as this is the only economic opportunity available to them (434). Another native Mozambican describes why he and other members of his displaced community are involved in poaching; "We are using rhino horn to free ourselves" (436). This entire system is backed by North American trophy hunters who are unaware of the consequences of their conservation-minded actions. This was made clear when prospective trophy hunting clients were surveyed, and $86 \%$ were more willing to purchase a hunt if local communities would benefit (Lindsey et al. 360).

As has been discussed, the hunting industry in Africa is plagued with problems and rooted in neo-colonialism. Hunters' newfound interests in conservation are contradictory, and often serve only to improve their own public- and self-image, as well as ensure that hunting for sport will exist in the future. Many non-hunting North Americans have begun to recognize the dangers of the trophy hunting industry. In 2015, the cracks in the hunting industry were opened wide for the public to see when an American dentist illegally killed a radio-collared lion, named Cecil. This event was broadcasted widely by American media outlets; however, "Much of the media discourse... [was] emotional and polarized, focusing on animal welfare and debating the value of hunting as a conservation tool" (Lindsey et al. 296). Though this occasion brought trophy hunting into the eye of the public, it resulted only in so-called 'animal-lovers' and high-profile celebrities crying for the arrest of the hunter who killed Cecil, and an outright ban on trophy hunting around the world. Comprehension of the hunting industry was completely lacking, which could be seen from the fact that discussions regarding native populations, who are the most affected by the hunting industry, were non-existent (296). Nonetheless, the conversation continues today, with millions of signatures on Change.org petitions calling for a variety of measures to be taken regarding the trophy hunting industry. One petition, entitled "United Nations: BAN Trophy Hunting. STOP Poachers. END Imports" (Pivorroto), is intended to be sent to Secretary-General of United Nations, António Guterres. However, it is riddled with grammatical errors, hunting stereotypes, and a complete lack of understanding of what trophy hunting entails. This petition raises an important question; what right do people in the West have to try to change other countries? The very foundation of why trophy hunting is harmful is because it is rooted in neo-colonial practices. However, is it not a form of neo-colonialism to attempt to enforce laws and regulations on African industries from abroad? Felix Marnewecke, a professional hunter and guide in Africa, asks this question: "who gives anyone the right, sitting in another continent, to preach to us how we should manage our wildlife?" (Chancellor). This leads to an important discussion; what can be done to improve the trophy hunting industry in Africa?

\section{Possibilities for Improving the Trophy Hunting Industry in Africa}

When Namibia achieved independence from South Africa in 1990, game populations were at historic lows (Martin). In an effort to encourage a rebound in both wildlife and nonhuntingrelated tourism, the new government organized rural populations into communities to control vast areas of land, which were restocked with game. Each community was vested with the right to manage its own wildlife resources (Martin). Naidoo et al. investigated the benefits of the hunting industry on seventy-seven communal conservancies in Namibia between 1998 and 2013 and found that trophy hunting can benefit 
both locals and wildlife (Naidoo 628). Namibia's method of conservation, which is centred around local indigenous communities, supplies salaries for conservation employees, money for community projects, and meat to local families when an animal is hunted(632). Between the years of 2011 and 2013, hunting generated $\$ 5.41$ million dollars in revenue for Namibian locals (636).

Namibia demonstrates that trophy hunting can improve the wellbeing of local human and animal populations in Africa. However, this is only possible when conservation organizations neglect the current utilitarian approaches to wildlife protection that "favour the rich, powerful, and foreign at the expense of local communities" (Naidoo 629). For this to occur, North American trophy hunters must abandon their neo-colonial ideologies of Africa. Wildlife must no longer be seen merely as trophies, but as living organisms in a dynamic environment. The African continent must not be seen as some sort of unadulterated 'Eden' (Hubschle 440), but as a complex set of ecosystems, interwoven with many nations, each of whom have their own desires, leaderships, and histories. Indigenous peoples must also be viewed in a different light, no longer as just guides in the hunt (Whittle 196), or mere obstacles to conservation. Instead, they must be treated as human beings and included in the trophy hunting narrative. After all, they are often the best suited to protect and care for the lands and wildlife of Africa, for it is what many indigenous communities have been doing for thousands of years (Beinhart et al. 59). Though the trophy hunting industry is clearly riddled with flaws, the potential for fostering a more sustainable industry exists. With "scientifically determined wildlife population estimates, comprehensive quotas which are enforced, reputable and honest outfitters, transparent and accountable revenue collection and disbursement mechanisms, competent management and oversight of the industry, and fair distribution of proceeds at the local level" (Baker 319), trophy hunting can become a tool for conservation. Though above all else, it is crucial for trophy hunters to become more educated about the implications of their involvement in African affairs. It is only then that they should use their voices and put their money toward bettering their sport.

Many of these suggestions for improving the hunting industry can be seen in the case of Namibia, where trophy hunting has had positive impact on animal populations, indigenous peoples, and the economy. Through the adoption of community-based natural resource management (CBNRM), rural communities and conservation efforts have been funded and developed by the trophy hunting industry (Nelson and Agrawal 558). According to Nelson and Agrawal, "The premise underlying CBNRM reforms is that sustainable management is most likely where local users are able to manage and extract benefits from natural resources" (558-559). In fact, "CBNRM efforts are a response to the reality that many cases of rural resource degradation occur because centralized management regimes in African states are often de facto open access regimes" (559). Namibian policymakers have found that "vesting local users with rights to manage, use or own resources is... a key corrective" to these centralized management systems which have been proven so problematic in the past, and continue to damage countless African nations (559). The case of Namibia illustrates that CBNRM reforms are a powerful tool for indigenous peoples to be engaged with their land once again. In this way, CBNRM reforms help to combat neo-colonial attitudes and the power narrative that exists in the trophy hunting industry.

\section{Conclusion}

In the vast majority of cases, the modern trophy hunting industry in Africa, and its model for addressing issues in wildlife conservation, are ineffective. The rules and laws surrounding hunting are poorly regulated, and many are based on miscalculations and misunderstandings of animals and their behaviours. Hunting revenue frequently funds corrupt governments, 
as opposed to furthering conservation efforts. Even when conservation efforts are practiced, they frequently come at the cost of displacing local indigenous populations. The majority of these issues are rooted in colonial systems, which have evolved into modern neo-colonial behaviours that hinder the trophy hunting industry's success.

However, this does not mean that there is no hope for improvements. Aldo Leopold, ecologist and hunter in the early twentieth century, is admired by many modern-day trophy hunters (Simon 20). Leopold believed that the greatest threat to conservation is the trophy hunter who, in order to enjoy his sport, feels the need to "possess, invade, [and] appropriate" (30). Instead,
Leopold recommended, "the weaker interests of trophy hunters should be subordinated to humanity's stronger interests in wilderness preservation and... the 'biotic right' of other[s] to exist in their natural states" (Simon 25). This is incredibly relevant to the twenty-first century trophy hunting industry in Africa. Today, if trophy hunters see the wellbeing of others, both humans and animals alike, beyond their own selfinterests, they can abandon their neo-colonial tendencies. When this occurs, the trophy hunting industry may become a powerful force in the protection of wildlife, while allowing local African populations to have autonomy over, and thrive in, the savannah they call home.

\begin{abstract}
About the Author
Meghan Bird is a student of McMaster University's Interdisciplinary Arts and Science program. This past year, she completed the first year of her undergraduate education and spent much of her time exploring interdisciplinary writing, both within and outside her academic studies. Her writing and research interests are vast, and include history, politics, indigenous studies, animal behaviour and ecology, environmental studies, and psychology. Meghan was inspired to write this piece after an encounter with members of the trophy hunting community at a family wedding in 2016. She began researching the trophy hunting industry in an attempt to understand the psychology behind hunting, as well as whether trophy hunting can benefit African ecology and economics. Meghan published in the University of Waterloo's Journal of Integrative Research and Reflection because she was interested in further exploring and applying her interdisciplinary academic studies outside of her undergraduate program.
\end{abstract}




\section{References}

Antwi-Boateng, Osman. "New World Order Neo-Colonialism: A Contextual Comparison of Contemporary China and European Colonization in Africa." Journal of Pan-African Studies, vol. 10, no. 2, Apr. 2017, pp. 177-195.

Azzentine, Downes T. "Killing for Trophies: An Analysis of Global Trophy Hunting Trade." International Fund for Animal Welfare, International Fund for Animal Welfare.

Baker, Joni E. "Trophy Hunting as a Sustainable Use of Wildlife Resources in Southern and Eastern Africa." Journal of Sustainable Tourism, vol. 5, no. 3, 29 Mar. 2010, pp. 306-321., doi:10.1080/096695897 08667294.

Beinart, William, and Lotte Hughes. "Hunting and Wildlife in Southern Africa." Environment and Empire, Oxford University Press, 2010, pp. 58-75.

Cartmill, Matt. "Hunting and Humanity in Western Thought." Social Research, vol. 62, no. 3, 1995, pp. 773-786. JSTOR [JSTOR], doi:edsjsr.40971120.

Chancellor, David, et al. "Should We Kill Animals to Save Them?" Official Journal of The National Geographic Society, Oct. 2017, pp. 70-99.

Christ, Costas. "Shoot One to Save the Rest?" Intelligent Travel, National Geographic, 1 Aug. 2014, intelligenttravel.nationalgeographic.com/2014/07/22/shoot-one-to-save-the-rest/? ga=2 .90752604.73888 7161.1511708730-2072458523.1507329237.

Hemingway, Ernest. Green Hills of Africa. SchoİNingh, 1956.

Hubschle, Annette. "The Social Economy of Rhino Poaching: Of Economic Freedom Fighters, Professional Hunters and Marginalized Local People." Current Sociology, vol. 65, no. 3, 2016, pp. 427-447. Academic OneFile [Gale], doi: 10.1177/0011392116673210.

Lindsey, P A, et al. "Economic and Conservation Significance of the Trophy Hunting Industry in Sub-Saharan Africa." Biological Conservation, vol. 134, 24 Apr. 2006, pp. 355-369. Science Direct, doi:10.1016/j.biocon.2006.09.005.

Lindsey, Peter A, et al. "Life after Cecil: Channeling Global Outrage into Funding for Conservation in Africa." The Journal for the Society of Conservation Biology, vol. 9, no. 4, 2016, pp. 296301. Open Access, doi: 10.1111/conl.12224.

Lindsey, Peter A., et al. "Trophy Hunting and Conservation in Africa: Problems and One Potential Solution." Conservation Biology, vol. 21, no. 3, 20 Nov. 2006, pp. 880-883. JSTOR [JSTOR], doi:10.1111/j.1523-1739.2006.00594.x.

MacDonald, David W., et al. "Lions, trophy hunting and beyond: knowledge gaps and why they matter." Mammal Review, vol. 47, no. 431 July 2017, pp. 247-253., doi: 10/mam,1206.

MacDonald, Kenneth Lian. "Global Hunting Grounds: Power, Scale and Ecology in the Negotiation of Conservation." Cultural Geographies, vol. 12, 1 July 2005, pp. 259-291. Social Sciences Citation Index, doi:10.1191/1474474005eu330oa.

Martin, Glen. "Lionizing Cecil Makes Us Feel Good, But a Trophy Hunt Ban Will Just Accelerate Slaughter." California Magazine, 3 Aug. 2015.

Muposhi, Victor K, et al. "Ecological, Physiological, Genetic Trade-Offs and Socio-Economic Implications of Trophy Hunting as a Conservation Tool." Journal of Animal and Plant Sciences, vol. 27, no. 1, 28 Feb. 2017, pp. 2-13. Academic OneFile [Gale].

Naidoo, Robin, et al. "Complementary Benefits of Tourism and Hunting to Communal Conservancies in Namibia." Conservation Biology, vol. 30, no. 6, June 2016, pp. 628-638. Wiley Subscription Services. 
Nelson, Fred, and Arun Agrawal. "Patronage or Participation? Community-Based Natural Resource Management Reform in Sub-Saharan Africa." Development and Change, vol.39, no. 4, 2008, pp. 557-585., doi:10.1111/j.1467-7660.2008.00496.x.

Nelson, Fred. "Black Rhinoceros Conservation and Trophy Hunting in Southern Africa: Implications of Recent Policy Changes." Endangered Species Update, vol. 23, no. 2, 2006, pp. 61-69. Academic OneFile [Gale],doi:http://www.umich.edu.libaccess.lib.mcmaster.ca/ esupdate/.

Pearce, Fred. "A License to Kill a Rhino." New Scientist, vol. 221, no. 2952, 18 Jan. 2014, pp. 4-4. Science Direct, doi:https://doi.org/10.1016/S0262-40791460102-0.

Pivorotto, Giovanni. "Sign the Petition." Change.org, www.change.org/p/ryan-zinke-ban-elephantivory-and-tusks-from-being-imported-intotheusource_location=search.

Sexton, Jennifer. "Hunting (Hobby)." Salem Press Encyclopedia, Research Starters, 2015,eds.a.ebsc ohost.com.libaccess.lib.mcmaster.ca/eds/detail/detail?vid=1\&sid=a541769a-e162-45ea-bd10-b 0c65bfc97cc\%40sessionmgr4010\&bdata=JnNpdGU9ZWRzLWxpdmUmc2NvcGU9c210ZQ\% $3 \mathrm{~d} \% 3 \mathrm{~d} \# \mathrm{AN}=100259105 \& \mathrm{db}=$ ers.

Simon, Alexander. "Against Trophy Hunting: A Marxian-Leopoldian Critique." Monthly Review, vol. 68, no. 4, Sept. 2016, pp. 17-31. Political Science Database.doi: http://libaccess.mcmaster .ca.libaccess.lib.mc master.ca/login?url=https://search-proquest-com.libaccess.lib.mcmaster.ca /docview/1815627053?account id=12347.

Whittle, Matthew. "Lost Trophies: Hunting and the Imperial Souvenir in Walton Ford's Pancha Tantra." The Journal of Commonwealth Literature, vol. 51, no. 2, 2016, pp. 196-210. Scholars Portal Journals, doi: 10.1177/0021989415624957 